\title{
CLASSICAL AND MOLECULAR APPROACHES FOR IDENTIFICATION OF RHIZOBIUM LEGUMINOSARIUM, AZOTOBACTER CHROOCOCCUM AND BACILLUS MEGATERIUM
}

\author{
TALABANI, SH. K. ${ }^{1 *}-$ FAtTAH, O. A. ${ }^{2}-$ KHIDER, A. K. ${ }^{1}$ \\ ${ }^{2}$ Soil and Water Sciences Department, College of Agricultural Sciences, University of Sulaimani, \\ Sulaimani, Kurdistan Region, Iraq \\ e-mail: omar.fattah@univsul.edu.iq; phone: +964-770-153-6011 \\ ${ }^{1}$ Biology Department, College of Education Scientific, University of Salahaddin, Erbil, Kurdistan \\ Region, Iraq \\ e-mail: dradelkamal51@yahoo.com phone:+964-750-447-2908 \\ *Corresponding author \\ e-mail: shahen.fazil @ univsul.edu.iq; phone: +964-770-158-6531
}

(Received $15^{\text {th }}$ May 2019; accepted $16^{\text {th }}$ Jul 2019)

\begin{abstract}
The present study aimed to identify of Rhizobium leguminosarium from Broad bean nodules, Azotobacter chrococcum and Bacillus megaterium from the soil in Sulaimani city/Iraq. Cultural characteristics showed that the colonies of bacteria were circular, smooth convex, and white color in Rhizobium leguminosarium and Bacillus megaterium, while creamy colored for Azotobacter chrococcum. The isolated bacteria were motile, rod, and gram-negative in Rhizobium leguminosarium and Azotobacter chrococcum, and gram-positive in Bacillus megaterium. Biochemical tests found that Rhizobium leguminosarium was positive for Catalase and negative for Indole Production, Methyl Red, Vogas Proskauer, Citrate Utilization and Gelatinase, Azotobacter chrococcum was positive for Catalase and Citrate Utilization, while Bacillus megaterium was positive for Catalase, Citrate Utilization and Gelatinase. Rhizobium leguminosarium utilized Starch Glucose, Mannitol, Galactose, Raffinose, Trehalose, Mannose and Xylose, but Azotobacter chrococcum did not utilize Galactose and xylose, while Bacillus megaterium did not utilize Trehalose. The molecular method based on the detection of plasmid DNA, nod D2 and nodD3 in Rhizobium leguminosarium, chromosomal DNA, nif $\mathrm{H} 2$ and nif $\mathrm{H} 3$ in Azotobacter chrococcum, genomic DNA and two random primers in Bacillus megaterium on gel electrophoresis have been successfully applied. We conclude that cultural, morphological and biochemical tests used for identification of these isolates was equivalent to the molecular-based method.
\end{abstract}

Keywords: biological nitrogen fixation, nod and nif genes, phosphate solubilization, PCR, gel electrophoresis

\section{Introduction}

Rhizobia are soil bacteria able to form nodules and establish a symbiosis with the roots of leguminous plants. During the symbiotic process, rhizobia reduce atmospheric nitrogen into a form directly assimilated by plants (ammonium) (Berrada and Fikri-Benbrahim, 2014). Azotobacter is an aerobic and free-living bacterium that can fix atmospheric nitrogen into the soil. Plants are able to utilize the ammonia as a nutrient (Biomate India, 2008). Bacillus megaterium is a gram-positive bacteria; it has a very efficient protein secretion system, grow on several different and cheap carbon sources, lack endotoxins, and are nonpathogenic. Proteins produced from and with it are of great industrial importance (Bunk et al., 2010). B. megaterium has the ability to solubilize phosphorus in the soil (Patel et al., 2016).

Nitrogen $(\mathrm{N})$ and Phosphorus $(\mathrm{P})$ are mineral nutrients often limiting plant growth because they are required in large amounts in relation to their availability in the soil 
(Harpole et al., 2011). Biological Nitrogen Fixation (BNF) is known to be a key to sustain agriculture and to reduce soil fertility decline (Kahindi et al., 2009). (BNF) is an efficient source of fixed N2 that plays an important role in land remediation (Mohammadi et al., 2012). Nitrogen fixation in symbionts and free-living microbes is catalyzed by nitrogenase; an enzyme complex encoded nifDK and nif $\mathrm{H}$ genes. Nitrogenase itself consists of a molybdenum-iron protein $(\mathrm{MoFe})$, subunit I and an iron-containing protein (Fe) subunit II. This biological process between Rhizobium strains and their legume partners can happen under low levels of available nitrogen with the help of many different genes such as a nod, nif, fix, production of polysaccharides, competition, infection process, and host specificity. NodD is appositive transcription regulator from the Lysr family and present in all rhizobia (Shamseldin, 2013). The structural nif genes from taxonomically diverse microbes are nearly identical and function in a similar manner to encode nitrogenase (Ruvkin et al., 1980). Azotobacter spp. studies on the genetics in this genus should take into consideration their nif genes which are responsible for fixing nitrogen (Dashti, 2011; Khider, 2011; Abid, 2013; Mohamed, 2017). The nifH gene is the biomarker most widely used to study the ecology and evolution of nitrogen-fixing bacteria (Raymond et al., 2004). Phosphate solubilization ability of microorganisms is associated with the release of low molecular weight organic acids (Puenta et al., 2004). The phosphate solubilization ability of microorganisms is regulated by several genes (Young and Lai, 2008), these genes are induced under phosphate starvation and constitute the Pho regulation (Bagyaraj et al., 2000). Bacillus megaterium var. phosphaticum was used to create a bio-preparation called Phosphobucterin with the purpose of enhancing mineral phosphorus solubilization (Sylvia et al., 1999).

The present study was carried out to compare two strategies for the isolation and identification of Rhizobium leguminosarium from bean nodules, Azotobacter chroococcum and Bacillus megaterium from soil depending on classical phenotypic approaches and through molecular methods by detection of nod $\mathrm{D}$ genes in $R$. leguminosarium and nif $\mathrm{H}$ genes in $A$. chroococcum and cheek the presence of $B$. megaterium that reported in different researches to do significant role in biological nitrogen fixation and phosphorus solubilization up to date. We used the molecular methods addition to the classical taxonomical process to support and to be sure that the bacteria which identified by the classical taxonomical process are same using molecular methods or not, because often the tests or characteristics of the classical taxonomical process of many bacterial species are similar which in some cases make the identification difficult. So, this classification should be confirmed and supported by molecular examination. This study consider the importance report and the first time identified of these bacteria depending on molecular approach in Bakrajow soil in Sulaimani city, Kurdistan region, Iraq.

\section{Materials and methods}

\section{Isolation of bacteria}

\section{Rhizobium leguminosarium spp.}

Nodulated Broad bean was selected from the organic farm of Bakrajow; the plant washed thoroughly with running tap water, then healthy, unbroken, firm and pink nodules were selected for the isolation. Isolation of Rhizobium was done on Yeast Extract Mannitol Agar (YEMA) (Handley et al,. 1998; Castro et al., 2003; Kucuk et al., 2006). 
The selected nodules were repeatedly washed in sterile water for 3-4 min, then washed with $70 \%$ ethyl alcohol, next rewashed with sterile water, after that crushed with a sterile glass rod. The resulting suspension was streaked on YEMA medium and incubated at 28 ${ }^{\circ} \mathrm{C}$ for 2-3 days. The developed colonies were isolated and purified then identified (Agrawal et al., 2012).

\section{Azotobacter chroococcum spp.}

Modified Ashby's Medium (MAM) was used as the specific A. chroococcum medium (Astafyeva and Shalabayeva, 2016). Two grams of soil samples were added to $500 \mathrm{ml}$ Erlenmeyer flasks containing $100 \mathrm{ml}$ (MAM), then stirred on rotary shaker $180 \mathrm{rpm}$ for $10 \mathrm{~min}$, streaked out on (MAM) and incubated at $28 \pm 2{ }^{\circ} \mathrm{C}$ for $2-5$ days to be checked for purity (Marwa et al., 2010).

\section{Bacillus megaterium}

B. megaterium was isolated through suspending $10 \mathrm{~g}$ of soil in $100 \mathrm{ml}$ distilled water in a conical flask. Aerobic spore formers pasteurized a diluted soil sample at $80{ }^{\circ} \mathrm{C}$ for $10-15 \mathrm{~min}$ and serial dilutions were made from soil suspension, then $100 \mu \mathrm{l}$ of soil suspension at different dilutions powered onto the surface of Sperber's medium which is a selective medium for isolating B. megaterium. Incubated at $28-30{ }^{\circ} \mathrm{C}$ for $48 \mathrm{~h}$. Developed colonies of $B$. megaterium appearing on the plates were observed (Shiva et al., 2010).

\section{Purification of bacteria}

A single colony of each isolated bacteria ( $48 \mathrm{~h}$ old surface film) was streaked on their selective media; the growth was observed depending on the type of bacteria, $R$. leguminosarium and B. megaterium after $24-48 \mathrm{~h}$ and $A$. chroococcum after 3-7 days at $28{ }^{\circ} \mathrm{C}$ of incubation. The well separated and apparently uncontamination colonies appearing on the plates were streaked on agar medium, plating and picking were repeated at least 4-5 times (Ausubel et al., 1987).

\section{Identification of isolated bacteria by cultural and microscopical characteristics}

Cultural characteristics for each isolated were achieved on their media including the shape, color and type of the colonies after $24-48 \mathrm{~h}$ for $R$. leguminosarium and $B$. megaterium, and after 3-7 days for A. chroococcum at $28^{\circ} \mathrm{C}$ of incubation, while microscopical tests for each isolated were carried out for fixed smears using gram stain, shape, and motility followed the method described by Mahon and Manuselis (2000).

\section{Identification of isolated bacteria by biochemical tests}

The isolated bacteria were characterized biochemically such as Catalase test and Gelatinase test according to Forbes et al. (2002), methyl red, vogas proskauer and Indole production depending on Atlas et al. (1995) and Citrate utilization according to Mahon and Manuselis (2000). 


\section{Identification of isolated bacteria by carbohydrate fermentation test}

Carbohydrate fermentation profiles were conducted in Yeast manitol broth for $R$. leguminosarium, Modified Ashby's broth for A. chroococcum and Sperber's broth for B. megaterium as carbon sources amended with $0.004 \%$ of chlorophenol red and $1 \%$ of one of the investigated sugars namely: Starch, Glucose, Mannitol, Galactose, Raffinose, Trehalose, Mannose and Xylose, growth was observed after 5 and even up to 15 days at $28{ }^{\circ} \mathrm{C}$ of incubation. Acid and gas production were detected by observing the color change of chlorophenol red from red to yellow (acid) and accumulation of gas in Durham's tube (gas) (Forbes et al., 2002).

\section{Maintenance and storage of bacterial culture}

The cultures were maintained for a short time at slant medium, and for a long time without losing their activity in $20 \%$ glycerol and stored at $-70{ }^{\circ} \mathrm{C}$ (Ausubel et al., 1987).

\section{Identification of bacteria by molecular basis protocol}

\section{Extraction of Chromosomal, Genome and Plasmid DNA from bacteria}

Plasmid DNA was extracted from pure culture of $R$. leguminosarium using Genet bio, PrmePrep Plasmid DNA isolation kit, and Chromosomal DNA from pure culture of A. chroococcum and Genome DNA from pure culture of B. megaterium were extracted using the PrestoTM Mini gDNA Bacteria Kit Protocol.

\section{PCR amplification conditions}

The conditions of PCR amplification: for nodD2 and nodD3 were performed according to the modified method of Del Cerro et al. (2015a) at cycling conditions consisted of a single cycle of $95{ }^{\circ} \mathrm{C}$ for $10 \mathrm{~min}$, followed by 45 cycles of $95{ }^{\circ} \mathrm{C}$ for $2 \mathrm{~min}, 60^{\circ} \mathrm{C}$ for $30 \mathrm{~s}$ and $72{ }^{\circ} \mathrm{C}$ for $30 \mathrm{~s}$, and a final extension cycle at $72{ }^{\circ} \mathrm{C}$ for $6 \mathrm{~min}$., while PCR reactions for nifH2 and nifH3 were done depending on Setubal et al. (2009), and for random primers 1 and 2 of $B$. megaterium carried out depending on Patil et al. (2013). The forward, reverse and random primers are shown in Table 1.

\section{Gel electrophoresis}

The PCR products were checked by electrophoresis by dissolve $0.5,1,1.5$ and $2 \%$ (w/v) agarose gel depending on the size of amplified DNA fragments in $100 \mathrm{ml}$ IX TBE buffer by heat in microwave oven for $3 \mathrm{~min}$, then cooled solvent to $45^{\circ} \mathrm{C}$ at room temperature, Gels were stained in ethidium bromide and then covered the gel tank by lid and electrophoresis was run at $(80 \mathrm{~V}, 100 \mathrm{~V}) 10 \mathrm{~V} / \mathrm{cm}$. DNA fragments were visualized at $312 \mathrm{~nm}$ with a UV-transilluminator Image (Helmut et al., 2004).

\section{Results}

\section{Isolation}

$R$. leguminosairum was isolated from Broad bean plant nodules using yeast mannitol agar medium, and colonies observation were done after 2-3 days of incubation at $28 \pm 2{ }^{\circ} \mathrm{C}$ (Fig. 1). The nodules were found positive for the presence of $R$. leguminosarium. A. chroococcum was isolated from the soil using Modified Ashby's 
medium, and the growth was observed after 3-7 days of incubation at $28{ }^{\circ} \mathrm{C}$ (Fig. 2). B. megaterium was isolated from soil using Sperber's medium, and the colonies were observed on the plates after $48 \mathrm{~h}$ of incubation at $28-30{ }^{\circ} \mathrm{C}$ (Fig. 3). Then the bacteria were characterized morphologically, biochemically and molecularly.

Table 1. The forward, reverse and random primers used

\begin{tabular}{|c|c|c|c|}
\hline Primer & Sequence (5'-3') & Nucleotide & Reference \\
\hline $\operatorname{nod} \mathrm{D} 2-\mathrm{F}-$ & (GTA GGC CAT AAT GTC CAG A) & 19 & \multirow{2}{*}{ Del Cerro et al., 2015a } \\
\hline $\operatorname{nodD} 2-\mathrm{R}-$ & (GCG GCT TTA TAC TCA CCA) & 18 & \\
\hline nodD3- F- & (GAG CTA CCT CGA CTG CTA) & 18 & \multirow{2}{*}{ Del Cerro et al., $2015 \mathrm{~b}$} \\
\hline nodD3- R- & (CTA CCG CCA TGA TCA CCA) & 18 & \\
\hline nifH2- F- & (CGCCGGCGCAGTGTTTGCGG) & 20 & \multirow{2}{*}{ Setubal et al., 2009} \\
\hline nifH2 -R- & (CACTCGTTGCAGCTGTCGGC) & 20 & \\
\hline nifH3- F- & (CGATGACTGAAGACTGAACGAG) & 22 & \multirow{2}{*}{ Setubal et al., 2009} \\
\hline nifH3 -R- & (AAGGTGCGGTCAGGAGAGAA) & 20 & \\
\hline Random primer1 & (GGT GCG GGA A) & 10 & \multirow{2}{*}{ Patil et al., 2013} \\
\hline Random primer2 & $($ GTA GTC ATA T) & 10 & \\
\hline
\end{tabular}

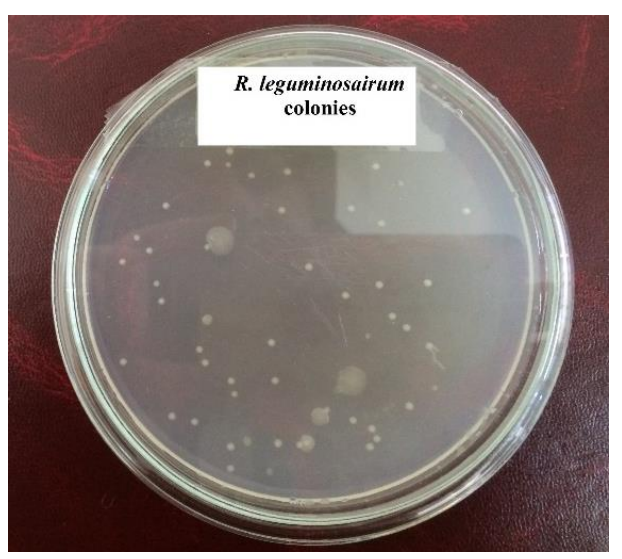

Figure 1. Single colonies of $R$. leguminosarium growth on YEMA medium

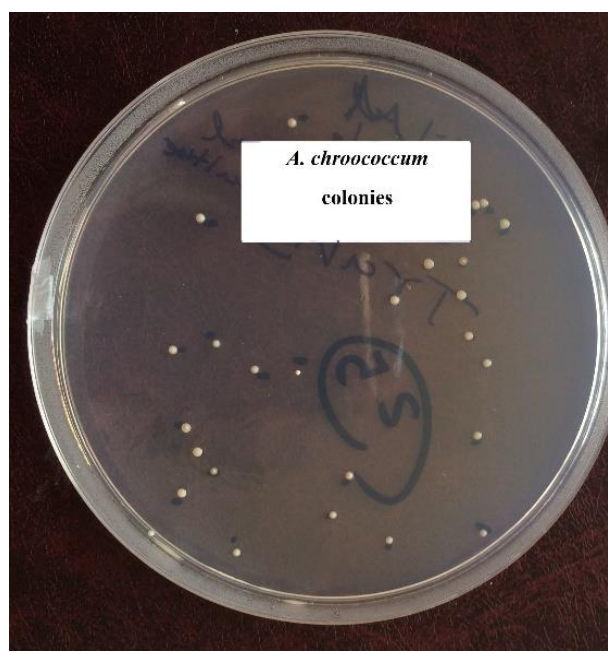

Figure 2. Single colonies of A. chroococcum growth on modified Ashby's medium 


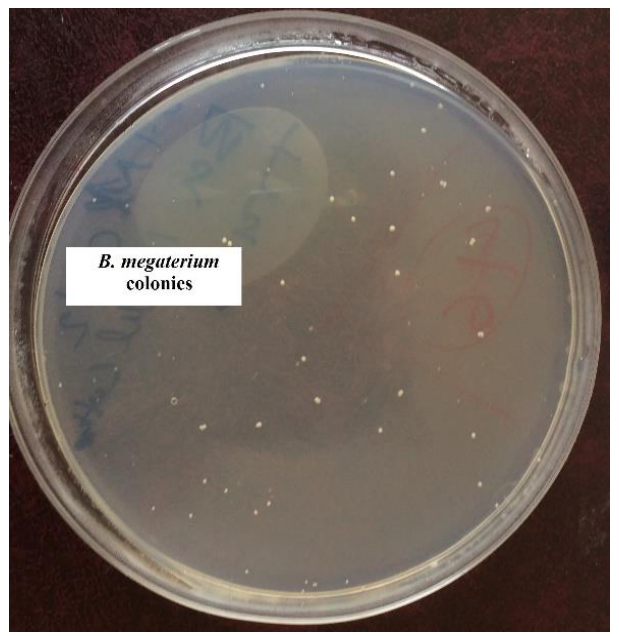

Figure 3. Single colonies of B. megaterium growth on Sperber's medium

\section{Identification of isolated bacteria by the morphological and biochemical characteristics}

To identify the species, the following were determined: the growth, morphological, biochemical properties, and carbohydrate fermentation tests according to Brenner et al. (2005).

Table 2 represents cultural and microscopical characteristics of $R$. leguminosarium, $A$. chroococcum and B. megaterium. The colonies of all the bacteria were circular in shape and smooth convex in type, but in color, $R$. leguminosarium and $B$. megaterium were white while $A$. chroococcum was creamy color. The all bacteria were rod in shape and motile, but in gram stain, $R$. leguminosarium and A. chroococcum were negative while $B$. megaterium was positive.

Table 2. The cultural and microscopical tests of the isolated Rhizobium leguminosarium, Azotobacter chroococcum and Bacillus megaterium

\begin{tabular}{c|c|c|c}
\hline \multirow{2}{*}{ Test } & \multicolumn{3}{|c}{ Bacteria } \\
\cline { 2 - 4 } & Rhizobium leguminosarium & Azotobacter chroococcum & Bacillus megaterium \\
\hline Colonies & & & \\
Shape & Circular & Circular & Circular \\
Color & White & Creamy & White \\
Type & Smooth convex & Smooth convex & Smooth convex \\
\hline Bacterium & & - & + \\
Gram Stain & - & Rod & Rod \\
Shape & Rod & Flagella & Flagella \\
Motile & Flagella
\end{tabular}

Table 3 represents the biochemical characterizations of $R$. leguminosarium, $A$. chroococcum and B. megaterium. All the bacteria were found positive for Catalase test, and negative for Indole Production, Methyl Red, Vogas Proskauer tests, but in Citrate Utilization was positive in $A$. chroococcum and $B$. megaterium, and negative for $R$. 
leguminosarium, while Gelatinase test was negative for $R$. leguminosarium and $A$. chroococcum and positive for B. megaterium.

Table 3. The biochemical characteristics of the isolated Rhizobium leguminosarium, Azotobacter chroococcum and Bacillus megaterium

\begin{tabular}{c|c|c|c}
\hline \multirow{2}{*}{ Characteristics } & \multicolumn{3}{|c}{ Bacteria } \\
\cline { 2 - 4 } & $\begin{array}{c}\text { Rhizobium } \\
\text { leguminosarium }\end{array}$ & Azotobacter chroococcum & Bacillus megaterium \\
\hline Catalase & + & + & + \\
Indole Production & - & - & - \\
Methyl Red & - & - & - \\
Vogas Proskauer & - & - & - \\
Citrate Utilization & - & + & + \\
Gelatinase & - & - & + \\
\hline
\end{tabular}

$R$. leguminosarium, A. chroococcum and B. Megaterium were also examined for fermentation of the various sugars, Table 4 shows that the $R$. leguminosarium found positive for assimilation of all sugars, A. chroococcum found negative for assimilation of Galactose and xylose while positive for other sugars, and B. megaterium found negative assimilation for Trehalose but positive for others.

Table 4. The Carbohydrate fermentation tests of the isolated Rhizobium leguminosarium, Azotobacter chroococcum and Bacillus megaterium

\begin{tabular}{c|c|c|c}
\hline \multirow{2}{*}{ Carbon sources } & \multicolumn{3}{|c}{ Bacteria } \\
\cline { 2 - 4 } & Rhizobium leguminosarium & Azotobacter chroococcum & Bacillus megaterium \\
\hline Starch & + & + & + \\
Glucose & + & + & + \\
Mannitol & + & + & + \\
Galactose & + & - & + \\
Raffinose & + & + & + \\
Trehalose & + & + & - \\
Mannose & + & + & + \\
Xylose & + & - & + \\
\hline
\end{tabular}

\section{Identification of bacteria by the molecular basis}

Moreover based on the molecular method, plasmid DNA and nodD genes of $R$. leguminosarium, chromosomal DNA and nif $\mathrm{H}$ genes of $A$. chroococcum, and genome DNA and random primers of $B$. megaterium were detected.

The chromosomal DNA from A. chroococcum, genome DNA from B. megaterium and plasmid DNA from $R$. leguminosarium were detected on the agarose gel electrophoresis, the result shows in Figure 4, lane 2, 4, 6 respectively.

The PCR was carried out for all tested isolates to check the presence of nodD2 and nodD3 genes in $R$. leguminosarium, nif $\mathrm{H} 2$ and nifH3 genes in A. chroococcum, and to know the presence of the $B$. megaterium in the region using two random primers. Their 
banding patterns of DNA on agarose gel electrophoresis were compared with their references' primers. The PCR products for $R$. leguminosarium were: nod $\mathrm{D} 2(100 \mathrm{bp})$ (Fig. 5) and nodD3 (150 bp) (Fig. 6), for A. chroococcum were: nifH2 (250 bp) (Fig. 7), and nifH3 (130 bp) (Fig. 8) lanes 2, while these bands did not appear in the negative control (lanes 3 ) in all figures.

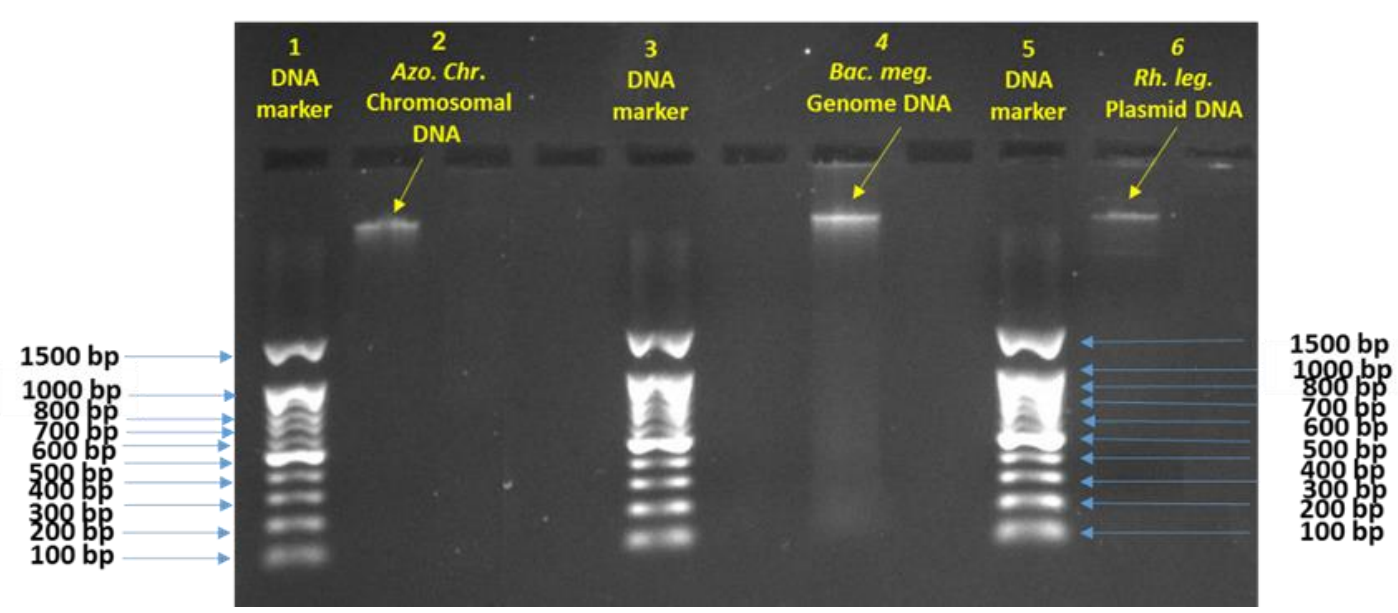

Figure 4. Agarose gel electrophoresis shows DNA marker lanes (1, 3, and 5), extracted chromosomal DNA from A. chroococcum lane 2, genome DNA from B. megaterium lane 4, and plasmid DNA from R. leguminosarium lane 6

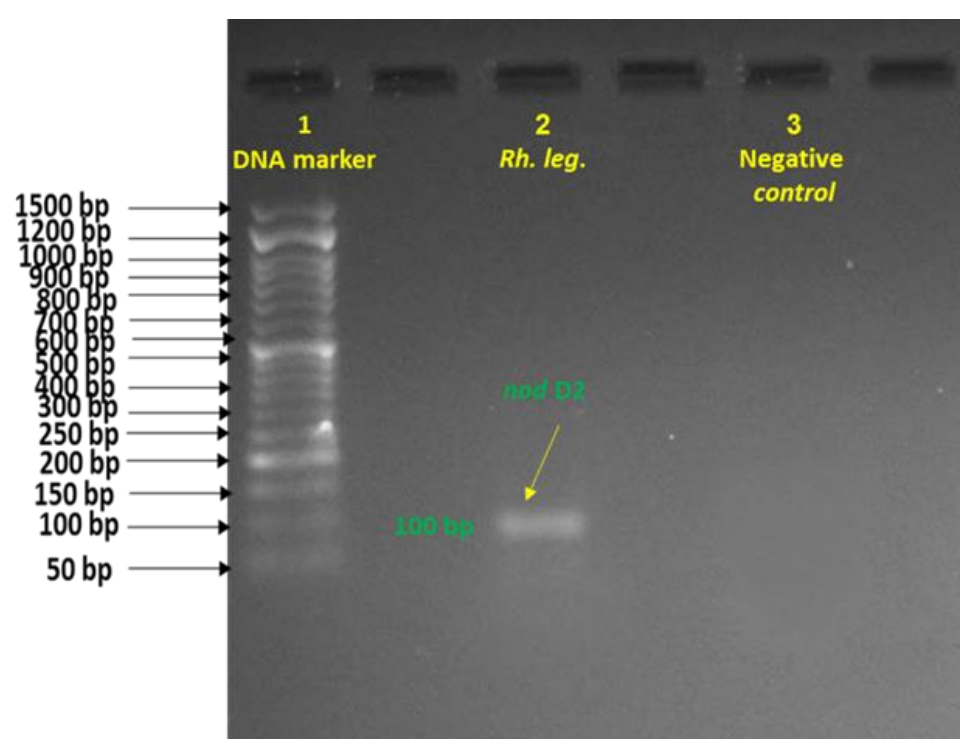

Figure 5. Agarose gel electrophoresis shows the PCR amplified products of the nodD2 gene (100 bp). Lane 1: DNA marker, lane 2: R. leguminosarium (+ve PCR product), lane 3: negative control (-ve PCR product)

For $B$. megaterium using random primers (1 and 2$)$ were obtained high amplification rate and reproducible banding pattern which confirmed the existence of $B$. megaterium in the regions (Fig. 9) lanes 2 and 3. Therefore, all the bacteria that classified depending on the traditional approach were compared with that of molecular-based methods. 


$$
\text { - } 12499 \text { - }
$$

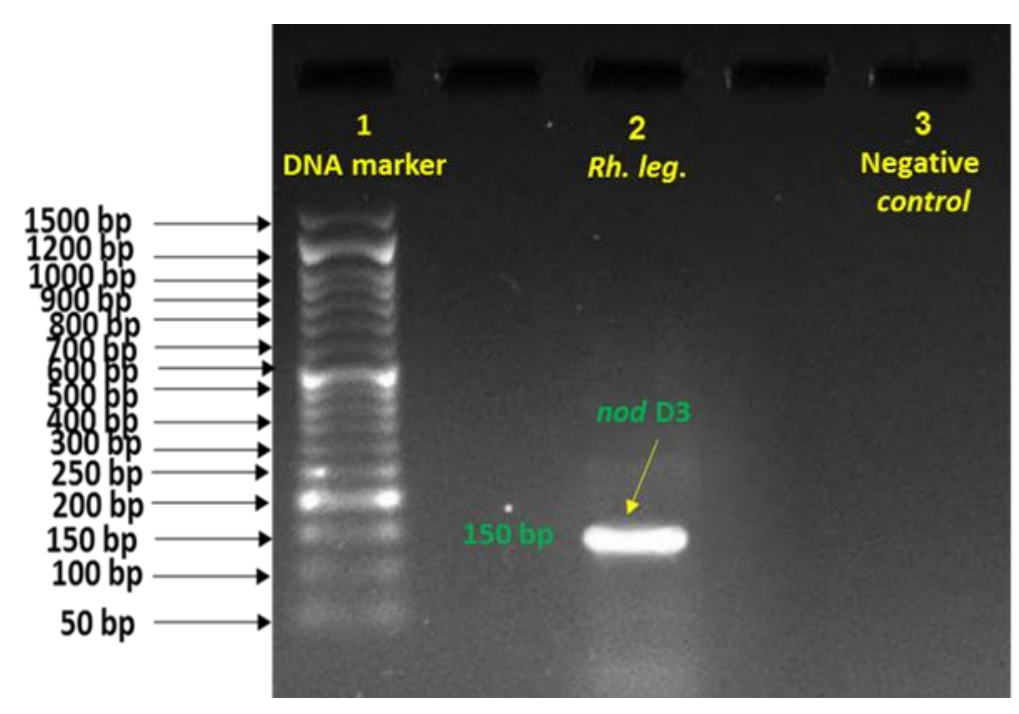

Figure 6. Agarose gel electrophoresis shows the PCR amplified products of the nodD3 gene (150 bp). Lane 1: DNA marker, lane 2: R. leguminosarium (+ve PCR product), lane 3: negative control (-ve PCR product)

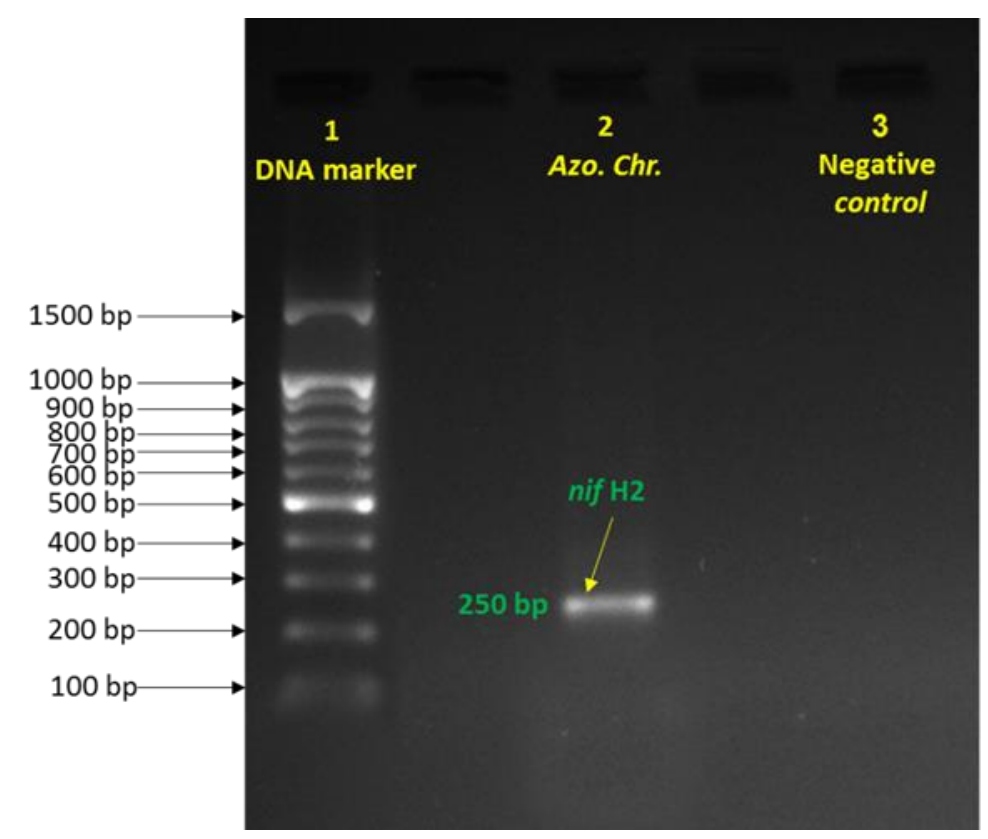

Figure 7. Agarose gel electrophoresis shows the PCR amplified products of the nifH2 gene (250 bp). Lane 1: DNA marker, lane 2: A. chroococcum (+ve PCR product), lane 3: negative control (-ve PCR product)

\section{Discussion}

This research work aimed to compare two different methods reported in the literature for the isolations of $R$. leguminosarium from Broad bean nodules, A. chroococcum and B. megaterium bacteria from Bakrajow soil in Sulaimani city, Iraq, in order to prove the presence and identify these bacteria. Different criteria have been presented by several researchers to delimit characteristic which can be used as a key for identification of all studied bacteria, generally included morphological, cultural, biochemical and molecular 
characteristics, highlighting the points which may be used as the diagnostic indications. All bacteria were processed through the characteristics using common procedures for isolation and identification of all isolated bacteria using selective media for each bacteria.

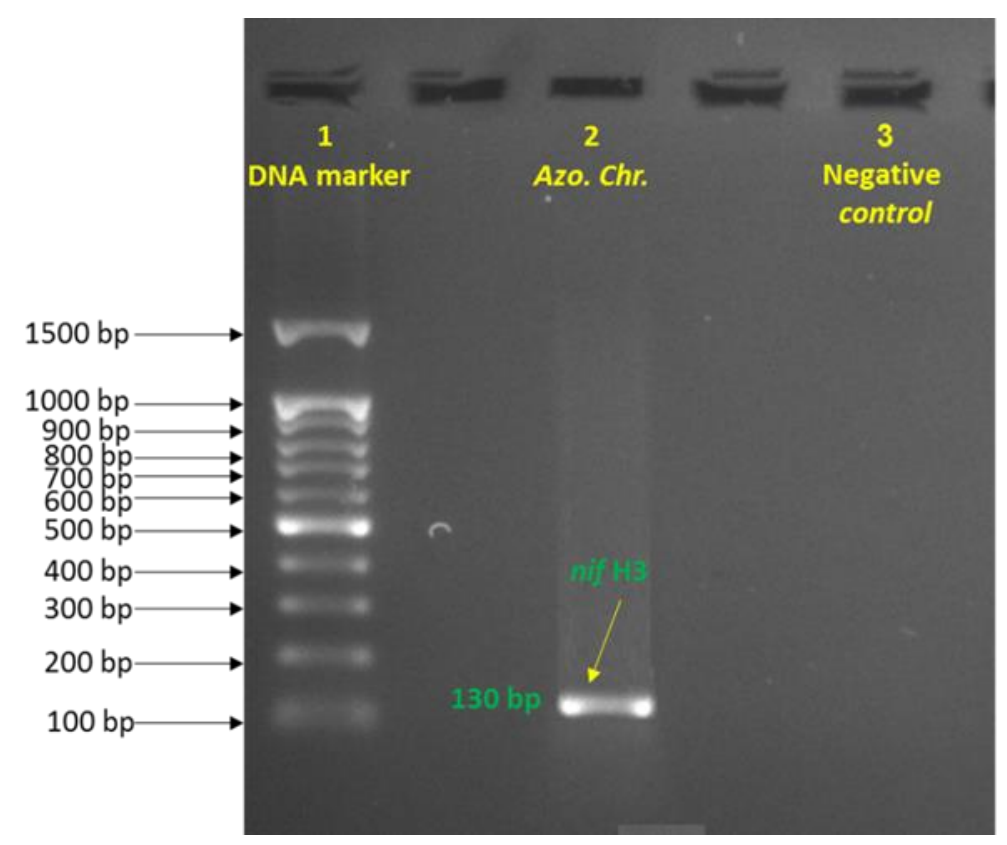

Figure 8. Agarose gel electrophoresis shows the PCR amplified products of the nifH3 gene (130 bp). Lane 1: DNA marker, lane 2: A. chroococcum (+ve PCR product), lane 3: negative control (-ve PCR product)

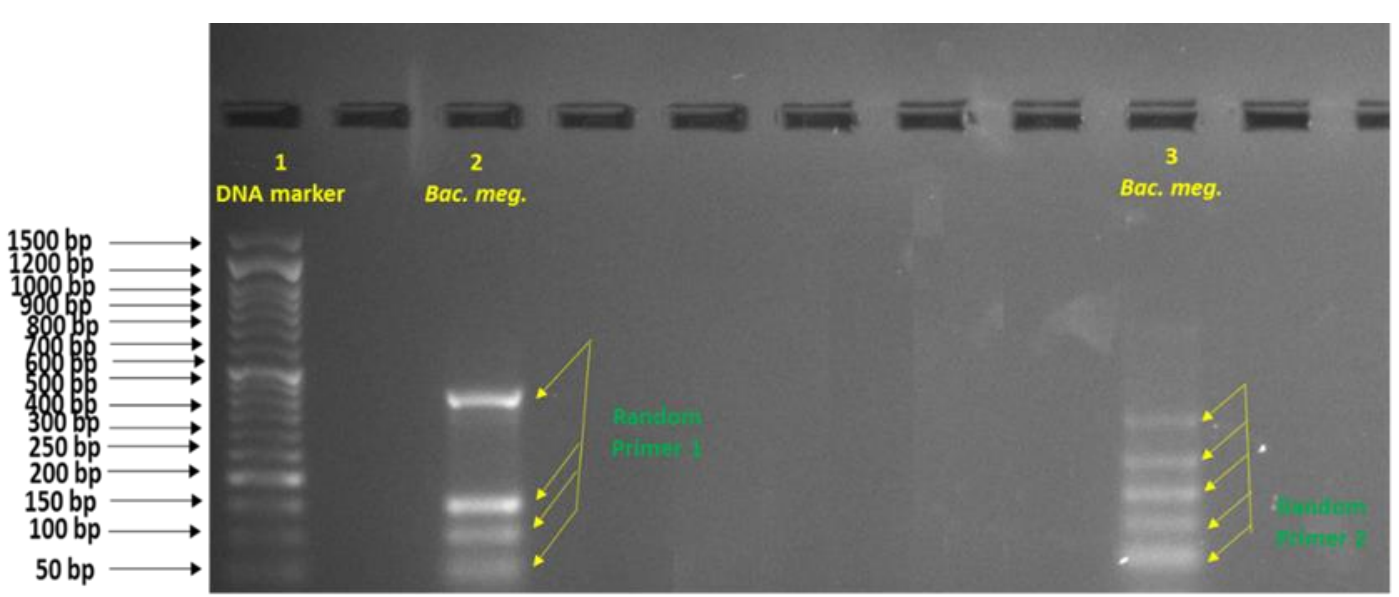

Figure 9. Agarose gel electrophoresis shows the PCR amplified products of the B. megaterium isolate generated using 10-mer random primers: Lane 1: DNA marker, lanes 2 and 3: random primers 1 and 2 respectively (+ve PCR products)

The nodules of Broad bean showed presences of $R$. leguminosarium basing on the characteristics, the colony morphology on a selective medium is clearly recognizable (Fig. 1), so the isolated bacteria classified as R. leguminosarium when the colonies were circular in shape, white color, smooth convex in type, and the bacterium was motile, rod 
and gram-negative. The biochemical characterization found positive for Catalase test, and negative for other biochemical tests, when $R$. leguminosarium utilized starch and all other sugars and produced of gas and acid, considered the important observations to classify the isolated bacteria as $R$. leguminosarium, Depending on these characteristics the isolated Rhizobium was classified as $R$. leguminosarium according to Brenner et al. (2005). Same results have also reported by other researchers like Shoukry et al. (2013), Datta et al. (2015) and Tesema (2018).

Obviously molecular characterization of the isolated Rhizobium identified based on the extraction and purification of plasmid DNA from pure culture of $R$. leguminosarium to detect of nodD genes, because nodulation genes (nod genes) are located on the plasmid which is also called mega plasmid (Kumari and Sinha, 2011), which have been successfully applied and the banding pattern of plasmid DNA on agarose gel electrophoresis showed in Figure 4 lane 6. The PCR was carried out for isolated bacteria by using complementary primers in order to amplify and cheek the presence of $n o d \mathrm{D} 2$ and nod $\mathrm{D} 3$ for isolated Rhizobium which identified as $R$. leguminosarium by the traditional approach. The nodD2 and nodD3 genes were (100 bp) and (150 bp) in Figures 5 and 6, lanes 2, respectively. Nod D genes act as the family of regulatory (Kidaj and Wielbo, 2010). In legume nitrogen-fixing symbioses, rhizobial nod genes are obligatory for initiating infection thread formation and root nodule development (Fujishige et al., 2007). NodD is the core signaling protein, reacting to plant flavonoids then binding to nod boxes, binding sites upstream of nod genes, typically nodA and/or $\operatorname{nod} \mathrm{B}$, triggering the expression of a $\operatorname{nod}$ gene cascade and thus the construction of the Nod Factor (Jones et al., 2007). The nod gene is controlled by nodD gene. NodD proteins act as a transcriptional activator of inducible nod gene (Kumari and Sinha, 2011). So the importance of nod D in nitrogen fixation process gives importance to our choice of these genes (nod 2 and nodD3) which are located on the plasmid for this study. The common nodulation genes (nodDABC) are found in all bacteria that nodulate legumes (Giraud et al., 2007). Also Black et al. (2012) reported that all fourteen species of Rhizobium contained $\operatorname{nod} \mathrm{D}, \operatorname{nod} \mathrm{E}, \operatorname{nod} \mathrm{G}, \operatorname{nod} \mathrm{I}, \operatorname{nod} \mathrm{M}, \operatorname{nod} \mathrm{P}, \operatorname{nod} \mathrm{Q}, \operatorname{nod} \mathrm{V}$, and $\operatorname{nod} \mathrm{W}$. As well Rossen et al. (1985), Hu et al. (2000) and Zeze et al. (2001) showed and confirmed presence of nodD in $R$. leguminosarium.

The soil sample was processed through the colony characteristics, morphology, and biochemical tests, using common procedures for isolation and identification of $A$. chroococcum and B. megaterium species in the soil using selective media for each bacteria. The sample showed presences of the two species depending on their characteristics.

The colony morphology of A. chroococcum on Modified Ashby's medium clearly appeared (Fig. 2), and the medium that used is to be selective enough, so the isolated classified as A. chroococcum when the colonies were circular in shape, creamy color, smooth convex in type and the bacterium was motile, rod and gram-negative, in biochemical characterization found positive for Catalase test and Citrate utilization, but negative for other biochemical tests. The important observations that the isolates classified as A. chroococcum when utilized different carbon sources such as starch, glucose, mannitol, raffinose, trehalose and mannose. Marwa et al. (2010), Dashti (2011), Khider (2012), Abid (2013) and Mohamed (2017) obtained same results when they isolated different strains of Azotobacter from the soil of different regions in Kurdistan-Iraq. The isolated Azotobacter was classified as A. chroococcum according to Brenner et al. (2005) in Bergey's Manual of Determinative Bacteriology. 
Indeed molecular characterization of the isolated Azotobacter based on the extraction of chromosomal DNA from pure culture of A. chroococcum and the banding pattern of the chromosomal DNA on agarose gel electrophoresis showed in Figure 4 lane 2. Then the nifH genes detected on chromosomal DNA of A. chroococcum, because nif genes in some free-living bacteria are located on the chromosome (Kumari and Sinha, 2011). Using of the complementary primers to well-conserved regions in the bacterial genome, led to amplify the nif genes (nitrogenase genes) nif $\mathrm{H} 2$ and nif $\mathrm{H} 3$ genes by PCR which identified as $A$. chrococcum by classical approach. The nif $\mathrm{H} 2$ and nifH3 genes were (250 bp) and (130 bp) in Figures 7 and 8, lanes 2, respectively. NifH acts as dinitrogenase reductase, obligate electron donor to dinitrogenase during dinitrogenase turnover and is required for FeMo-Co biosynthesis and apodinitrogenase maturation (Shamseldin, 2013). The region of chromosome which contain nif $\mathrm{K}$, nif $\mathrm{D}$, nif $\mathrm{M}$, nif A, $n i f \mathrm{~N}, n i f \mathrm{~B}, n i f \mathrm{Q}, n i f \mathrm{Z}, n i f \mathrm{P}, n i f \mathrm{~F}, n i f \mathrm{~W}, n i f \mathrm{~B}, n i f \mathrm{~L}$, and $n i f \mathrm{Y}$ genes are located between the fragment of chromosome which contains nif $\mathrm{H} 2$ and $n i f \mathrm{H} 3$ and the fragment contain nif $\mathrm{V}$, nifS, and nif $\mathrm{U}$ (Hamilton et al., 2011). Importance of region of nif $\mathrm{H} 2$ and nif $\mathrm{H} 3$ genes on chromosome took into consideration to select these genes for this study. Previous studies by Kirshtein et al. (1991), Ueda et al. (1995), Zehr et al. (2003), Aquilantia et al. (2004), Mary Ann and Virginia (2007), Dashti (2011), Hamilton et al. (2011), Khider (2012), Abid (2013) and Mohamed (2017) indicated that N-fixing bacteria were investigated by the diversity of nitrogenase genes in different environments, through amplification of nif genes, i.e., nif $\mathrm{H}$, nif $\mathrm{D}$, nif $\mathrm{V}$, nif $\mathrm{K}$, nif $\mathrm{U}$ which encode nitrogenase complex from cultivated organisms.

Sperber's medium was used as a selective medium to identify the B. megaterium depending on the colonies (Fig. 3) and bacterium morphology, and other characteristics, the isolated classified as $B$. megaterium when the colonies were circular in shape, white color, smooth convex in type and the bacterium was motile, rod and gram-positive. In biochemical characterization found positive for Catalase, Citrate utilization and Gelatinase tests, but negative for Indole Production, Methyl Red and Vogas Proskauer. $B$. megaterium had the ability to utilize all carbon sources except trehalose. Other researchers have also reported same results such as Dunca et al. (2005), Tenzing et al. (2016), Patel et al. (2016) and Environment and Climate Change Canada (2018). So the isolated Bacillus was classified and identified as B. megaterium according to Brenner et al. (2005) in Bergey's Manual of Systematic Bacteriology.

Molecular characterization of the isolated B. megaterium was identified through extraction of the genome DNA from pure culture of $B$. megaterium culture, and the banding pattern of the genome DNA on agarose gel electrophoresis showed in Figure 4 lane 4. The PCR was carried out for isolated bacteria by using two random primers 1 and 2 to detect and cheek the presence of $B$. megaterium in the region which identified as $B$. megaterium by classical approach. In the results found that the banding patterns were intense, clear and reproducible in B. megaterium (Fig. 9). Previous studies by Shiva et al. (2010) and Patil et al. (2013) indicated the presence of B. megaterium in the different area by these primers.

\section{Conclusion}

As the result of the morphological and growth characteristics, physiological and biochemical properties of all isolated bacteria according to Brenner et al. (2005) in Bergey's Manual of Systematic Bacteriology, and based on the molecular methods: the 
isolated Rhizobium was taxonomically classified as Rhizobium leguminosarium, isolated Azotobacter as Azotobacter chroococcum and isolated Bacillus as Bacillus megaterium, so the results of the classical approaches were parallel with molecular methods. Our recommendation is using molecular method with multiplex PCR for one step identification of each bacteria is faster, more accurate and low cost. Detection of other nod and nif genes required further work.

Acknowledgments. We wish to thank Dr. Zaid Khalaf Khidhir from Faculty of the Agricultural Sciences University of Sulaimani for his cooperation; we also wish to thank Professor Dr. Nawroz Abdul-razzak Tahir from Faculty of the Agricultural Sciences University of Sulaimani for his helpful in the molecular part.

\section{REFERENCES}

[1] Abid, S. A. (2013). Microbiological and molecular biology study of Azotobacter species from Bakrajow soil in Sulaimani. - M.Sc. Thesis. Faculty of Agricultural Sciences, University of Sulaimani, Kurdistan.

[2] Agrawal, P. K., Agrawal, S., Singh, U., Katiyar, N., Verma, S. K. (2012): Phenotypic characterization of Rhizobia from legumes and its application as a bioinoculant. - Journal of Agricultural Technology 8(2): 681-692.

[3] Aquilantia, L., Favillib, F., Clementi, F. (2004): Comparison of different strategies for isolation and preliminary identification of Azotobacter from soil samples. - Soil Biol. Biochem. 36: 1475-1483.

[4] Astafyeva, Y., Shalabayeva, K. (2016): Dependence of Azotobacter chroococcum culture growth rate on salt concentrations. - Proceedings of Engineering for Rural Development, 25-27 May, 2016, Jelgava, Latvia.

[5] Atlas, R. M., Alfred, A. E., Lawrence, C. P. (1995): Laboratory Manual of Experimental Microbiology. - Mosby-Year Book Inc., USA.

[6] Ausuble, F. M., Kingstonm, R. E., Bernt, R., Moore, D. D., Smith, J. A,. Seidman, J. G., Stuhl, K. (1987): Current Protocols in Molecular Biology. - John Wiley and Sons, Inc., New York.

[7] Bagyaraj, D. J., Krishnaray, P. U., Khanuja, S. P. (2000): Mineral phosphate solubilization Agronomic implications, mechanism and molecular genetics. - Ind. Natu. Sci. Acad. (PINSA) 3: 69-82.

[8] Berrada, H., Fikri-Benbrahim, K. (2014): Taxonomy of the Rhizobia: current perspectives. - British Microbiology Research Journal 4(6): 616-639. www.sciencedomain.org.

[9] Biomate India (2008): Project Report for Biofertilizer Laboratory and Production Unit, Inspired by Scientific Technology. An ISO 9001 Certified Company, Near Delhi Technological University (DCE). - Rohini, Delhi. www.biomateindia.com.

[10] Black, M., Moolhuijzen, P., Chapman, B., Barrero, R., Howieson, J., Hungria, M., Bellgard, M. (2012): The genetics of symbiotic nitrogen fixation: comparative genomics of 14 Rhizobia strains by resolution of protein clusters. - Genes 3: 138-166. DOI: 10.3390. www.mdpi.com/journal/genes.

[11] Brenner, D. J., Noel, R. K., Staley, J. T. (2005): The Proteobacteria. Part B: The Gammaproteobacteria. - In: Garrity, G. M. (ed.) Bergey's Manual of Systematic Bacteriology. Second Ed. Springer Science and Business Media, Inc., New York.

[12] Bunk, B., Jahn, D., Biedendieck, R., Vary, S. P. (2010): Bacillus Megaterium and Other Bacilli: Industrial Applications. - In: Flickinger, M. C. (ed.) Encyclopedia of Industrial Biotechnology: Bioprocess, Bioseparation, and Cell Technology. Wiley, Hoboken, NJ. 
[13] Castro, I. V., Ferreira, E. M., McGrat, S. P. (2003): Survival and plasmid stability of rhizobia introduced into a contaminated soil. - Soil Biol. Biochem 35: 49-54.

[14] Dashti, A. M. K. (2011): Isolation and characterization of Azotobacter spp. in Erbil soils, and study the effect of biofertilzer (Azotobacter chroococcum and transconjugant Lactobacillus plantarum) on nutrient uptake by wheat. - Ph.D. Thesis. Ministry of High Education and Scientific Research, University of Salahaddin, Erbil, Kurdistan.

[15] Datta, A., Singh, R. K., Tabassum, S. (2015): Isolation, characterization and growth of Rhizobium strains under optimum conditions for effective biofertilizer production. - Int. J. Pharm. Sci. Rev. Res. 32(1): 199-208.

[16] Del Cerro, P., Rolla-Santos, A. A. P., Gomes, D. F., Marks, B. B., Pérez-Montaño, et al. (2015a). Regulatory nodD1 and nodD2 genes of Rhizobium tropici strain CIAT 899 and their roles in the early stages of molecular signaling and host-legume nodulation. - BMC Genomics 16(1): 251. DOI: 10.1186/s12864-015-1458-8.

[17] Del Cerro, P., Rolla-Santos, A. A. P., Gomes, D. F., Marks, B. B., Pérez-Montaño, F., et al. (2015b). Opening the "black box" of nodD3, nodD4 and nodD5 genes of Rhizobium tropici strain CIAT 899. - BMC Genomics 16: 864. DOI: 10.1186/s12864-015-2033-z.

[18] Dunca, S., Stefan, M., Nimitan, E., Ailesei, O. (2005): Microbiologcal study of a Bacillus megaterium strain with soil phosphorus solubilization potential. - Kom. J. Biol. Plant Biol. 49-50: 31-39.

[19] Environment and Climate Change Canada (2018): Final Screening Assessment of Bacillus megaterium. - Health Canada, Government of Canada.

[20] Forbes, B. A., Sahm, D. F., Weissfeld, A. S. (2002): Diagnostic Microbiology. 11th Ed. Mosby, Inc., USA.

[21] Fujishige, N. A., Lum, M. R., De Hoff, P. L., Whitelegge, J. P., Faull, K. F., Hirsch, A. M. (2007): Rhizobium common nod genes are required for biofilm formation. Molecular Microbiology 67(3): 504-515.

[22] Giraud, E., Moulin, L., Vallenet, D., Barbe, V., Cytryn, E., Avarre, J. C., Jaubert, M., et al. (2007): Legume symbioses: absence of Nod genes in photosynthetic bradyrhizobia.Science 316: 1307-1312.

[23] Hamilton, T. L., Marcus, L., Ray, D., Eric, S. B., Patricia, C., et al. (2011): Transcriptional profiling of nitrogen fixation in Azotobacter vinelandii. - J. Bacteriol. 193(17): 4477-4486.

[24] Handley, B. A., Hedges, A. J., Beringer, J. E. (1998): Importance of host plants for detecting the population diversity of Rhizobium leguminosarum biovar viciae in soil. Soil Biology \& Biochemistry 3: 241-249.

[25] Harpole, W. S., Ngai, J. T., Cleland, E. E., Seabloom, E. W., Borer, E. T., et al. (2011): Nutrient co-limitation of primary producer communities. - Ecol Lett 14: 852-62.

[26] Helmut, B. F., Widmer, W., Sigler, V., Zeyer, J. (2004): New molecular screening tools for analysis of free-living diazotrophs in soil. - Appl. Environ. Microbial 70: 240-247.

[27] Hu, H., Liu, S., Yang, Y., Chang, W., Honga, G. (2000): In Rhizobium leguminosarum, NodD represses its own transcription by competing with RNA polymerase for binding sites. - Nucleic Acids Research 28(14): 2784-2793.

[28] Jones, K. M., Kobayashi, H., Davies, B. W., Taga, M. E., Walker, G. C. (2007): How rhizobial symbionts invade plants: the Sinorhizobium-Medicago model. - Nat. Rev. Microbiol. 5: 619-633.

[29] Kahindi, K., Karanja, N., Gueye, M. (2009): Biological Nitrogen Fixation. - In: Doelle, H. W. et al. (eds.) Biotechnology. EOLSS, Oxford, UK.

[30] Khider, A. K. (2011): Chromosomal nif genes transfer by conjugation in nitrogen fixing Azotobacter chrococcum to Lactobacillus planetarium. - Current Research Journal of Biological Sciences 3: 155-164.

[31] Khider, A. K. (2012): Molecular study of nifH1, nifH2, nifH3, nifU, nifV, VF genes and classical approach carried out to identification of Azotobacter chrococcum from soil. Curr. Res. J. Biol. Sci. 4(5): 570-577. 
[32] Kidaj, D., Wielbo, J. (2010): Use of rhizobial Nod factors as biofertilizers for legumes. M. Curie-Sklodowska University, Lublin, Poland/Mikkeli, Finland.

[33] Kirshtein, J. D., Paerl, H., Zehr, W. J. (1991): Amplification, cloning and sequencing of a nif $\mathrm{H}$ segment from aquatic microorganisms and natural communities. - Appl. Environ. Microbiol. 57: 2645-2650.

[34] Kucuk, C. M., Kivanç, M., Kinaci, E. (2006): Characterization of Rhizobium Sp. isolated from bean. - Turk J. Biol. 30: 127-132.

[35] Kumari, S., Sinha, R. P. (2011): Symbiotic and Asymbiotic N2 Fixation. - In: Sinha, R. P. et al. (eds.) Advances in Life Sciences. I.K. International Publishing House Pvt. Ltd., New Delhi, Chap. 5, pp. 133-148.

[36] Mahon, C., Manuselis, G. (2000): Textbook of Diagnostic Microbiology. 2nd Ed. - W. B. Saunders Company, PA.

[37] Marwa, A. S., Elbaz, A. F., Ragab, A. A., Hamza, H. A., El Halafawy, K. A. (2010): Identification and characterization of Azotobacter chroococcum isolated from some Egyptian soils. - J. of Agricultural Chemistry and Biotechnology 1(2): 93-104.

[38] Mary Ann, M. E., Virginia, A. R. (2007): Genomes of sea microbes. - Oceanogr 20: 4755.

[39] Mohamed, A. S. A. (2017): Molecular study on isolated Azotobacter, Rhizobium and Bacillus megaterium var phosphaticum employment as biofertilizer. - Ph.D. thesis. Salahaddin University, Erbil, Kurdistan.

[40] Mohammadi, K., Sohrabi, Y., Heidari, G., Khalesro, S., Majidi, M. (2012): Effective factors on biological nitrogen fixation. - Afr. J. Agric. Res. 7(12): 1782-1788.

[41] Patel, G., Singh, S., Saxena, S. K., Kaur, K. J. (2016): Isolation, biochemical characterization and production of biofertilizer from Bacillus megaterium. - Int. J. Life Sci. Scienti. Res. 2(6): 749-752. DOI: 10.21276/ijlssr.2016.2.6.16.

[42] Patil, H. S. R., Naik, T. V., Avin, B. R. V., Sayeswara, H. A. (2013): Isolation and molecular characterization of Bacillus megaterium isolated from various agro climatic zones of Karnataka and its effect on medicinal plant Ruta gradiolus. - Curr Res Microbiol Biotechnol. 1(4): 173-182.

[43] Puenta, M. E., Bashan, Y., Li, C. Y., Lebsky, V. K. (2004): Microbial populations and activities in the rhizoplane of rock weather insert plants, root colonization and weathering of igneous rocks. - Plant. Biol. 6: 629-642.

[44] Raymond, J., Siefert, J. L., Staples, C. R., et al. (2004): The natural history of nitrogen fixation. - Mol. Biol. Evol. 21: 541-554.

[45] Rossen, L., Shearman, C. A., Johnston, A. W. B., Downiel, J. A. (1985): The nodD gene of Rhizobium leguminosarum is autoregulatory and in the presence of plant exudate induces the $\operatorname{nod} A, B, C$ genes. - The EMBO Journal 4(13A): 3369-3373.

[46] Ruvkin, G. B., Ausubel, F. M. (1980): Interspecies homology of nitrogenase genes. Proc. Natl. Acad Sci. USA 77: 191-195.

[47] Setubal, J. C., Santos, P. D., Goldman, B. S., Ertesvåg, H., Espin, G., et al. (2009): Genome sequence of Azotobacter vinelandii, an obligate aerobe specialized to support diverse anaerobic metabolic processes. - J. Bacteriol. 191: 4534-4545.

[48] Shamseldin, A. (2013): The role of different genes involoved in symbiotic nitrogen fixation - review. - Global Journal of Biotechnology \& Biochemistry 8(4): 84-94.

[49] Shiva, R. D. M., Mohan, B. K., Nataraja, S., Krishnappa, M., Abhilash, M. (2010): Isolation and molecular characterization of Bacillus megaterium isolated from different agro climatic zones of Karnataka and its effect on seed germination and plant growth of Sesamum indicum. - RJPBCS 1(3): 614.

[50] Shoukry, A. A., Khattab, A. A., Abou-Ellail. M., El-shabrawy, H. (2013): Molecular and biochemical characterization of new Rhizobium leguminosarum bio viciae strains isolated from different located of Egypt. - Journal of Applied Sciences Research 9(11): 58645877. 
[51] Sylvia, D. M., Fuhrmann, J. J., Hartel, P. G., Zuberer, D. A. (1999): Principles and Applications of soil Microbiology. - Prentice Hall Inc., Upper Saddle River, NJ.

[52] Tenzing, B. N., Pandiarajan, G., Makesh, K. B. (2016): Isolation, identification and characterization of phosphate solubilizing bacteria from different crop soils of Srivilliputtur Taluk, Virudhunagar District, Tamil Nadu. - Tropical Ecology 57(3): 465474.

[53] Tesema, W. M. (2018): Symbiotic and phenotypic characteristics of Rhizobia nodulating Faba bean (Vicia faba L.) from Bale zone, Oromiya Regional State, Ethiopia. - M.Sc. Thesis. Hawassa University, Hawassa, Ethiopia.

[54] Ueda, T., Suga, Y., Yahiro, N., Matsuguchi, T. (1995): Remarkable N2 fixing bacterial diversity detected in rice roots by molecular evolutionary analysis of nifH gene sequences. - J. Bacteriol. 177: 1414-1417.

[55] Young, C., Lai, W. A. (2008): Mechanism of phosphate solubilization and growth promotion by diverse bacteria. - Appl. Soil Ecol. 49: 72-79.

[56] Zehr, J. P., Jenkins, B. D., Shortand, S. M., Steward, G. F. (2003): Nitrogenase gene diversity and microbial community structure: a cross-system comparison. - Environ. Microbiol. 5 :539-554.

[57] Zeze, A., Mutch, L. A., Young, J. P. W. (2001): Direct amplification of nodD from community DNA reveals the genetic diversity of Rhizobium leguminosarum in soil. Environmental Microbiology 3(6): 363-370. 